\title{
RESEARCH TRENDS İN EDUCATIONAL TECHNOLOGY IN TURKEY: 2010-2018 YEAR THESIS AND META-ANALYSIS OF ARTICLES
}

\author{
Ezgi Pelin YILDIZ \\ Kafkas University Vocational School of Technical Sciences-Department of Computer \\ Programming, KARS, TURKEY
}

\begin{abstract}
The purpose of this research is the analysis using meta-analysis of studies in the field of Educational Technology in Turkey and in the field is to demonstrate how to get to that trend. For this purpose, a total of 263 studies were analyzed including 98 theses and 165 articles published between 2010-2018. Purpose sampling method was used when selecting publications. In the research, while selecting articles and theses; Turkey addressed; YOK Tez Tarama Database, Journal of Hacettepe University Faculty of Education, Educational Sciences : Theory \& Practice Journal, Education and Science Journal, Elementary Education Online Journal, The Turkish Online Journal of Education and The Turkish Online Journal of Educational Technology used in journals. Publications have been reviewed under 11 criteria. Index, year of publication, research scope, method, education level, sample, number of samples, data collection methods, analysis techniques, and research tendency, research topics in Educational Technology Research in Turkey has revealed. The data is interpreted based on percentage and frequency and the results are shown using the table.
\end{abstract}

\section{KEYWORDS}

Educational Technologies, Research Trends, Meta Analysis, Publication Classification.

\section{INTRODUCTION}

Educational Technology manages the fields of activity of personnel and teaching tools in humanmachine systems for a more effective learning-teaching process; It is a discipline based on applied scientific research that controls environmental factors, integrates theory and practice and continuously modernizes and improves educational activities (Alkan, 2011). The definition of educational technologies is most recently defined by AECT. Educational technologies according to this definition; it is the ethical implementation and study of technological processes and resources in order to support learning, and to design, use and coordinate the learning performance (AECT, 2004). With the developments in the information boom and the development of information and communication technologies, the theory, method and subject areas in which Education Technologies are affected in time have also changed. Constructivist learning theory and student-centered education approach have focused on these issues in educational technologies (Erdoğmuş and Çağıltay, 2009). In addition, Educational Technology is not a single area; it is a discipline covering very large areas. This discipline includes different fields such as primary education, high school, higher education and military. That is why; within the framework of this wide range of educational technologies, many studies have been carried out by researchers in Turkey and abroad.

Educational technology research falls into the general category of applied research. The basic 
approach is to take what basic research has established in areas such as the psychology of human learning and apply basic research findings, associated theories and prior applied research findings to improve learning and instruction with [and sometimes without] technology (Spector, 2013).

When we look at the literature, it is possible to mention the studies that determine trends in educational technology research. Cafarella, one of the pioneers of these studies, examined the trends in doctoral dissertations in the USA from 1977 to the present. According to the study, the trends in doctoral theses completed from 1977 to 1998; Educational Technologies has increased in favor of computer use in education, educational software design, individual differences and the effectiveness of computers in education. According to this study, the studies of media comparison (effect of media on learning) decreased and the use of qualitative research methods increased (Caffarella, 1999).

Tuncay, Keser and Uzunboylu conducted a meta-analysis in the field of educational technology research in 2010. As a result; 815 documents were examined; mixed learning, distance learning, distance learning, e-learning, information and communication technologies, instructional design, mobile learning, online education, online learning, web-based learning are frequently found in the keywords.

In Turkey Erdoğmuş and Cağıltay (2009), 248 master's research and have reached the doctoral thesis and methodology used in this thesis, sample creation techniques, research circles, has examined in terms of data collection, inventory and research topics that they use and they classified. When the theses are evaluated in terms of the subjects studied, the first two subject areas are; Media (Computer assisted education, distance education, internet, educational materials etc.), and Media Comparison studies. As the reason for the popularity of media comparison studies; the desire of researchers to prove the positive impact of the media on learning and the adoption of new media studies as a completely new study have been shown. When the research methods used in the theses are examined, experimental studies, screening method and case studies are the most frequently used research methods. In the sample selection; random sampling and random sampling methods are the most used sampling methods.

Sert (2010), master's thesis Social Science Citation Index's (SSCI) has made screening, published between 1989 to 2009 date, Turkey addressed and the audience was addressed by 173 article content analysis within Turkey. At the end of the study, it was revealed that learner outputs are the most studied subject.

Göktas, Kücük, Aydemir, Telli, Arpacık, Yıldırım and Reisoglu (2012), in their study between 2000-2009 revealed in 32 international journals published in 2010 under the SSCI Educational Technology field Turkey addressed 460 articles were analyzed using content analysis method. According to the results, it was revealed that most of the articles were researched in the fields of teaching environments and technology. In researches, quantitative methods and research method as a method of screening have been emphasized. As a data collection tool; survey; as a sample; objectives of sample; as data analysis; descriptive analysis was used in research.

\subsection{Purpose}

The aim of this study is; trends in research work in the field of Educational Technology in Turkey, classification is put forward by the publish.

\subsection{Importance}

This research resulted in the publication of studies in the execution of Educational Technology 
area between the years 2010-2018 index in Turkey, according to; release dates, number of authors, research fields, methods, educational level, sample, number of samples, data collection methods, analysis techniques, research purposes and research tendency and research topics in the field are examined. It is foreseen that the results obtained will provide guidance for the researchers who will work in this field. Other than this, researchers will be able to identify the gaps in the field and put forth new studies in this direction.

\subsection{Limitations}

This research includes studies between the years 2010-2018 in the field of Educational Technology held in Turkey and is limited to 263 publications.

\section{METHOD}

\subsection{Research Design}

This research is an example of a meta-analysis study included in content analysis studies. Meta analysis is a method to bring together the results obtained from the experiments and researches which are studied independently on the same subject, to explain the diversity in these results, to use the statistical methods to obtain more reliable and accurate results (Creswell, 2018). In this study, meta-analysis method was used in order to determine how a trend has been made in the field of Educational Technologies.

\subsection{Population and Sample}

The population of research, Education Technology consists of articles and theses published in databases published by the journal in the area of Turkey addressed. The sample of the study, which was published between the years 2010-2018 in the field of Educational Technology of Turkey addressed; YOK Tez Tarama Database, Journal of Hacettepe University Faculty of Education, Educational Sciences : Theory \& Practice Journal, Education and Science Journal, Elementary Education Online Journal, The Turkish Online Journal of Education and The Turkish Online Journal of Educational Technology.

\subsection{Data Collection}

The researches which were published by the researcher in the related journals in the last 8 years were examined and interpreted.

\section{Inclusion Criteria of the Data;}

- publication index names,

- publication dates,

- scope of research,

- the methods used,

- education level,

- sample group,

- number of samples,

- data collection methods,

- analysis techniques,

- research tendency,

- research topics 


\subsection{Data Analysis}

The data obtained in this research are presented as related tables. Purpose of this; to create a visualization of the work as well as the possibility of having an idea about the researches carried out at first sight. The data were interpreted based on percentage and frequency. After the general explanations under the tables, the similarities and differences in the studies were analyzed in detail using the meta-analysis method.

\subsection{Findings and Results}

In this section, the findings obtained from the analysis of the data are given.

Table 1. The Distribution of the studies in the field of Educational Technologies according to publication indexes

\begin{tabular}{lcc}
\hline Publication Indexes & F & \% \\
\hline YOK Tez Tarama Database & 88 & 30.1 \\
Education and Science Journal & 64 & 26.8 \\
Elementary Education Online Journal & 53 & 23.9 \\
Journal of Hacettepe University Faculty & 26 & 7.8 \\
of Education & 19 & 5.9 \\
Educational Sciences:Theory \& Practice & 8 & 3.2 \\
Journal & 5 & 2.3 \\
TOJDE & $\mathbf{2 6 3}$ & $\mathbf{1 0 0}$ \\
Total & $\mathbf{2 6 3}$ &
\end{tabular}

When the data in Table 1 are examined, it is revealed that the YOK Tez Tarama database has the most publication for the researches in the field of Educational Technologies. Of the 263 studies, 88 belong to YOK Tez Tarama and have a percentage of 33.6\%. It is thought that the reason of this situation is to include both master and doctorate theses in this area. In addition, the Journal of Education and Science is ranked second as the number of publications (64) and the percentage $(26.8 \%)$. 
Table 2. The Distribution of the studies in the field of Educational Technologies according to publication years

\begin{tabular}{lll}
\hline Publication Years & F & $\%$ \\
\hline 2018 & 37 & 20.9 \\
2017 & 46 & 23.9 \\
2016 & 37 & 10.9 \\
2014 & 30 & 8.8 \\
2015 & 30 & 8.8 \\
2012 & 27 & 8.1 \\
2010 & 21 & 6.5 \\
2011 & 20 & 6.2 \\
2013 & 15 & 5.9 \\
Total & $\mathbf{2 6 3}$ & $\mathbf{1 0 0}$ \\
\hline
\end{tabular}

According to the year classification in Table 2, it is seen that the most publications were made in 2017 year when the researches in the field of Educational Technologies were examined in the last 8 years. The number of publications in 2017 is 46 ; the percentage is $23.9 \%$. The year 2018 and 2016 are followed by the same number of publications and percentage (37 publications and $20.9 \%)$.

As can be seen in the table, researches in the field of Educational Technologies are continuing with increasing momentum in recent years. The reason for this increase; in recent years, information and communication technologies in the rapid development and changes occurred with the information boom is seen.

While these criteria were included in the study, Alkan (2011) used the items in the book of Education Technology (target, student, manpower, environment, methods and techniques, learning situations, evaluation and theoretical principles). According this;

Table 3. The distribution of scope of research in Educational Technologies

\begin{tabular}{lcc}
\hline Educational Technologies Items & F & $\%$ \\
\hline Student & 54 & 28.7 \\
Theoretical Principles & 34 & 9.9 \\
Manpower-Evaluation & 34 & 9.9 \\
Environment & 30 & 9.4 \\
Evaluation & 29 & 8.6 \\
Humanpower & 9 & 3.3 \\
\end{tabular}


Student-Evaluation

Method and Technic

9

9

Learning Situations

Student-Environment

Student-Learning Situations

Others

Target

Humanpower-Environment

Humanpower-Method and Technic

Humanpower- Theoretical Principles

Environment-Evaluation

Environment - Theoretical Principles

Environment-Method and Technic

Student- Humanpower

Student- Theoretical Principles

Student- Learning Situations

According to Table 3; the intensity of the Educational Technology elements included in the research; "student" was found to be on. According to Alkan (2011), this element, which is a raw material that is processed during the education, changes in terms of socio-economic situation, mental and physical development, expectations, developmental differences, different talent areas. On the other hand, due to the change in the quality of the educational objectives, it is also possible to determine the students' readiness to learn and to develop and disseminate the methods of determining the interests and abilities of their past lives. According to the table, "theoretical principles ", "manpower and evaluation" are followed by other research scopes. It is noteworthy that manpower is used in combination with other research scopes. In terms of manpower, in our age, the formation of new human organizations, change of school-environment relations, utilization of new technologies in education and application of new methodological approaches in 
International Journal of Computer- Aided Technologies (IJCAx) Vol.6, No.1/2, April 2019

processes changed the concept and practice of traditional teaching in education. Instead a brand new structure has been replaced; there is also the phenomenon of diversification of the tasks arising from the division of labor in the size of education today (Alkan, 2011).

Table 4. The distribution of studies in the field of Educational Technologies according to research methods

\begin{tabular}{lcc}
\hline Research Methods & F & $\%$ \\
\hline Scanning & 69 & 27.3 \\
Experimental Model & 58 & 19.6 \\
Meta analysis & 32 & 9.1 \\
Mixed Method & 25 & 7.0 \\
Qualitative Research Method & 25 & 7.0 \\
Scale Development & 18 & 6.3 \\
Case Study & 10 & 5.6 \\
Descriptive Scanning & 7 & 4.9 \\
Scale Adaptation & 4 & 2.8 \\
Database Scanning & 4 & 2.8 \\
Relational Scanning & 3 & 2.1 \\
Cross-sectional Scanning & 2 & 1.4 \\
Phenomenology & 2 & 1.4 \\
Thematic Content Analysis & 1 & 1.4 \\
Causal Comparison & 1 & 1.4 \\
Relating to Comparison & 1 & 1.4 \\
Data Mining & 1 & 1.4 \\
Toplam & $\mathbf{2 6 3}$ & $\mathbf{1 0 0}$ \\
\hline
\end{tabular}

According to Table 4; When the distribution of the studies in the field of Educational

Table 5. The distribution of the studies in the field of Educational Technologies according to the relevant educational level

\begin{tabular}{lcc}
\hline Education Level & F & $\%$ \\
\hline University & 115 & 52.5 \\
Primary School & 53 & 16.1 \\
Middle School & 53 & 16.1 \\
Middle-High School & 10 & 3.5 \\
High School & 9 & 2.8 \\
Distance Education & 8 & 2.1 \\
Primary-High School & 7 & 1.4 \\
Pimary-Middle-High School & 2 & 1.4 \\
Master & 1 & .7 \\
Primary-Middle & 1 & .7 \\
Special Education & 1 & .7 \\
Adult Education & 1 & .7 \\
Informal Education & 1 & .7 \\
Pre-School & 1 & .7 \\
Total & $\mathbf{2 6 3}$ & $\mathbf{1 0 0}$ \\
\hline
\end{tabular}


Technologies according to research methods are examined; it has been shown that the most commonly used research method is screening. This method is followed by the Experimental Model in 58 studies and a percentage of $19.6 \%$. In addition to these methods, mixed model, qualitative research, case study, scale development, descriptive scanning, scale adaptation, field literature review, relational screening method, case science, cross-sectional scanning, causal comparison, relationship determination, comparison with thematic content analysis and data mining are used. It is noteworthy that the scale development and adaptation methods are also used in the research in a significant way.

As seen in Table 5, when the distribution of the studies in the field of Educational Technologies according to educational levels is examined; It is seen that the researches are frequently done on the University "level. When it is examined with frequency and percentage, it is observed that it contains 115 publications and its percentage is 52.4\%. The reason for this situation; It is envisaged that an innovation or practices in Educational Technologies is first accepted to teacher candidates or instructors. "Primary School" and "Secondary School" education levels are followed by the same frequency and percentage. There are also researches covering all primary and secondary school-high school education levels. According to the table, Distance Education, Adult Education, Special Education and Informal Education have taken their places as educational levels in the studies conducted in the field of Educational Technologies.

Table 6. Distribution of the studies in the field of Educational Technologies according to the sample group

\begin{tabular}{lcc}
\hline Sample & F & $\%$ \\
\hline Middle School Students & 49 & 16.8 \\
Teacher Candidates Faculty of & 42 & 16.2 \\
Education & 39 & 15.7 \\
Teacher Candidates Department of & 28 & 12.6 \\
CEIT & 23 & 7.0 \\
Others & 21 & 5.9 \\
Primary School Students & 15 & 3.9 \\
Lectures & 12 & 3.1 \\
Teacher Candidates Department of & 8 & 2.1 \\
Classroom Teacher & 8 & 2.1 \\
Primary School Teacher & 7 & 1.8 \\
Computer Programming Students & 6 & 1.6 \\
Middle and High School Teacher & 3 & 1.5 \\
Formator Teachers & 2 & 1.4 \\
Teacher Candidates Department of & $\mathbf{2 6 3}$ & $\mathbf{1 0 0}$ \\
Pre-School Teacher & Distance Education Students &
\end{tabular}

When the distribution of the studies in the field of Educational Technologies according to Table 6 is analyzed according to the sample group, it is seen that the sample with the most frequency is on the incel "Middle School Students" (5th, 6th, 7th and 8th Grade). The reason for this; the impact of smart board and tablet use on the Secondary School Students within the scope of Fatih Project is predicted as an increase in research. Secondary school students are followed by Teacher Candidates Faculty of Education. In addition to these, articles and theses in the researches carried out by the meta-analysis method were also included in the sample group. 
Table 7. Distribution of the studies conducted in the field of Educational Technologies according to the number of samples

\begin{tabular}{lcc}
\hline Number of Samples & F & $\%$ \\
\hline 200 and more & 90 & 33.6 \\
$30-59$ & 52 & 25.6 \\
$1-29$ & 37 & 13.7 \\
$90-119$ & 21 & 7.5 \\
$60-89$ & 20 & 7.8 \\
$120-159$ & 19 & 5.9 \\
$160-200$ & 19 & 5.9 \\
Total & $\mathbf{2 5 8}$ & $\mathbf{1 0 0}$ \\
\hline
\end{tabular}

Table 8. Distribution of the studies in the field of Educational Technologies according to data collection method

\begin{tabular}{lcc}
\hline Data Collection Method & F & $\%$ \\
\hline scale & 85 & 32.5 \\
survey & 59 & 25.5 \\
interview & 40 & 20.5 \\
achievement test & 17 & 4.4 \\
scale-success test & 15 & 3.9 \\
survey-interview & 14 & 3.6 \\
video recordings & 2 & 1.4 \\
interview-survey & 2 & 1.4 \\
interview-observation & 2 & 1.4 \\
multiple choice testing & 2 & 1.4 \\
personal information form & 2 & 1.4 \\
software evaluation form & 1 & .7 \\
survey-voice recordings & 1 & .7 \\
open ended questions & 1 & .7 \\
scale-interview & 1 & .7 \\
document analysis & 1 & .7 \\
Total & $\mathbf{2 4 5}$ & $\mathbf{1 0 0}$ \\
\hline
\end{tabular}


International Journal of Computer- Aided Technologies (IJCAx) Vol.6, No.1/2, April 2019

Table 9. Distribution of the studies in the field of Educational Technologies according to analysis techniques

F $\%$

Analysis Techniques

T-test

Nonparametric Tests

Others

Frequency/Percent/Chart

Anova

Content Analysis

Cronbach alpha coefficient

Pearson Correlation coefficient

Pearson Correlation

Cronbach alpha coefficient

EFA ve CFA

Average/Standart Deviation

Ancova

Regrasyon Analysis

Manova

Factor Analysis

Total
59

23.5

59

23.5

43

21.3

24

9.3

15

6.3

9

2.3

7

1.8

7

1.8

7

1.8

7

6

5

5

5

3

2

263
1.5

1.3

1.3

.7

.5

1.8

1.3

100

Since of the publications reviewed 5 were report and 13 were meta analysis studies so data collection method was not included. Therefore, frequency and percentage were calculated by 245 research. When the Table 8 is examined, it is seen that the density is above the scale. The scale was followed by "survey", "interview" and "achievement test". According to the table, it is seen that qualitative researches are frequently used in data collection tools such as observation, interview, document analysis, video recordings, open-ended questions. 
International Journal of Computer- Aided Technologies (IJCAx) Vol.6, No.1/2, April 2019

When the table 9 is examined, it is revealed that the maximum frequency are $t$ test and Nonparametric tests. The percentage and frequency of both analysis techniques were found to be the same. Nonparametric tests; Chi-square, Mann-Whitney U, Wilcoxon tests are at the forefront. The reason for this frequency; the normal distribution of research data and the use of parametric tests for this purpose are foreseen. The ranking continues from "other" and "frequency / percentage / chart" to qualitative analysis techniques 
International Journal of Computer- Aided Technologies (IJCAx) Vol.6, No.1/2, April 2019

Table 10. Distribution of the studies in the field of Educational Technologies according to research tendency

\begin{tabular}{|c|c|c|}
\hline Research Tendency & $\mathbf{F}$ & $\%$ \\
\hline academic success & 34 & 12.1 \\
\hline perception & 28 & 11.1 \\
\hline attitude & 27 & 10.0 \\
\hline research tendency & 15 & 6.1 \\
\hline teacher opinions & 12 & 5.7 \\
\hline lecturer opinions & 9 & 4.4 \\
\hline anxiety & 8 & 3.7 \\
\hline professional development & 8 & 3.7 \\
\hline teacher candidate opinions & 8 & 3.7 \\
\hline perceptions of self-efficacy & 7 & 3.0 \\
\hline student opinions & 6 & 3.3 \\
\hline success and attitude & 6 & 3.3 \\
\hline behavioral intent & 5 & 2.6 \\
\hline pre-learning & 5 & 2.6 \\
\hline learning strategies & 4 & 1.9 \\
\hline In-service training qualifications & 2 & 1.4 \\
\hline perceptions of pre-service training & 2 & 1.4 \\
\hline quality standards & 2 & 1.4 \\
\hline satisfaction & 2 & 1.4 \\
\hline motivation & 2 & 1.4 \\
\hline permanent learning & 2 & 1.4 \\
\hline reading achievements & 2 & 1.4 \\
\hline negative attitudes & 2 & 1.4 \\
\hline student properties & 2 & 1.4 \\
\hline $\begin{array}{l}\text { student, teacher field expert } \\
\text { opinions }\end{array}$ & 1 & .7 \\
\hline lecturer opinions & 1 & .7 \\
\hline teacher candidate attitudes & 1 & .7 \\
\hline self-learning & 1 & .7 \\
\hline family opinions & 1 & .7 \\
\hline perceived learning & 1 & .7 \\
\hline self-perception & 1 & .7 \\
\hline $\begin{array}{l}\text { risks, factors affecting the risks } \\
\text { and their metadological } \\
\text { tendencies }\end{array}$ & 1 & .7 \\
\hline $\begin{array}{l}\text { technological Pedagogical Content } \\
\text { Knowledge }\end{array}$ & 1 & .7 \\
\hline technology planning opinions & 1 & .7 \\
\hline cognitive and social & 1 & .7 \\
\hline
\end{tabular}




\begin{tabular}{lcc} 
benefit perception & 1 & .7 \\
master student opinions & 1 & .7 \\
perceptions of superficial learning & 1 & .7 \\
Total & $\mathbf{2 1 8}$ & $\mathbf{1 0 0}$ \\
\hline
\end{tabular}

In a total of 218 publications, research tendency were clearly identified and frequency and percentage were defined. Accordingly, it is seen that the most frequent frequency is on "academic achievement" research tendency. Academic achievement is followed by "perception", "attitude" and "teacher opinions". In addition to these, "academician opinions", "anxiety", "professional development", "teacher candidate opinions" and "self-efficacy perceptions" are noteworthy.

Table 11. Distribution of the studies in the field of Educational Technologies according to research topics

\begin{tabular}{lll}
\hline Research Topics & F & $\%$ \\
\hline Technology Integration & 45 & 8.2 \\
Flipped Classroom & 31 & 7.5 \\
Information security & 28 & 7.1 \\
Digital Citizenship & 24 & 6.5 \\
Infographics & 22 & 6.2 \\
Online Learning & 15 & 5.4 \\
E-assessment & 11 & 4.6 \\
E-mentoring & 7 & 4.2 \\
E-book & 7 & 4.2 \\
Data mining & 6 & 3.5 \\
E-learning & 6 & 3.5 \\
Augmented Reality & 4 & 2.1 \\
Mobile Learning & 4 & 2.1 \\
MOOCS & 4 & 2.1 \\
Learning Management System & 4 & 2.1 \\
Eye tracking & 4 & 2.1 \\
Augmented Reality & 4 & 2.1 \\
Gamification & 2 & 2.1 \\
Game Based Learning & 4 & 2.1 \\
Instructional Technology & 4 & .7 \\
Cloud IT & 3 & .4 \\
Robotic & 3 & \\
Nomofobia & & \\
\hline
\end{tabular}


International Journal of Computer- Aided Technologies (IJCAx) Vol.6, No.1/2, April 2019

\begin{tabular}{lcc}
\hline Virtual Reality & 2 & .7 \\
Virtual Environment & 2 & .7 \\
Simulation & 2 & .7 \\
Coding & 2 & .7 \\
Wearable Technologies & 2 & .7 \\
Learning Environments & 2 & .7 \\
Research Tendency & 2 & .7 \\
Lifelong Learning & 2 & .7 \\
Constructivist Teaching Environments & 2 & .7 \\
Total & $\mathbf{2 6 3}$ & $\mathbf{1 0 0}$ \\
\hline
\end{tabular}

When the research subjects are examined according to the table below, it is seen that Technology Integration and Flipped Classroom subjects are preferred by researchers. Flipped classroom is a pedogogical method which means that activities that have traditionally taken place inside the classroom take place outside the classroom and vice versa (Uzunboylu and Karagozlu, 2015). Information security, digital citizenship and infographic issues are among the other research topics that follow these two issues. The study of new technologies in education has become popular. These results are expected to fill the gap in the area.

\section{Discussion}

Educational technology research falls into the general category of applied research. The basic approach is to take what basic research has established in areas such as the psychology of human learning and apply basic research findings, associated theories and prior applied research findings to improve learning and instruction with [and sometimes without] technology (Spector, 2013).

Educational technology can be defined as any digital device that aids or enhances student learning. In order to incorporate technology effectively into the classroom, it is important to understand the current trends in this area (Hughes, 2016).

This study was performed to determine trends in education technology publication completed in the last 8 years at major universities in Turkey is a general collective assessment.

In 2017, the frequency of publishing in the field of educational technologies is noteworthy. In the publications that have been completed in recent years, it is seen that the researches related to technology integration and filipped classroom have increased. It can be explained by the fact that information and communication technologies become an indispensable structure in human life. For all that very few studies on wearable technologies and robotic applications are noteworthy. These issues are now shown as trends in educational technologies (Sagbaş, Ballı and Yıldız, 2016). As a result; more work is needed.

It is observed that the publication is mainly based on quantitative research paradigm. There is a lack of studies designed with a qualitative or mixed model. Observational, interview and document analysis data collection tools are also scarce since qualitative studies are few. More 
International Journal of Computer- Aided Technologies (IJCAx) Vol.6, No.1/2, April 2019

recently, experimental research has increased. This result is promising for educational technologies.

It was determined that the studies were mostly directed to university education level. Howevers it was determined that the studies were mostly directed to middle school students according to sample group.

\section{SUGGESTIONS}

In summary; it is foreseen that the results obtained from the research can be useful in terms of seeing the strengths and weaknesses of the studies carried out in the field of Educational Technologies Research and it can be used as an effective and determining source in guiding the future studies. In addition, it was found appropriate to include the following suggestions within the findings of the research;

- Future studies can be structured by screening a greater number of journals to cover a larger process.

- Increasing the number of publications for qualitative and mixed methods in order to carry out the educational researches towards international tendethis article is presented in WCES 2019 in Italy Milano. ncy.

This article is presented in WCES (World Conference on Educational Science) 2019 in Italy Milano.

\section{REFERENCES}

[1] AECT, Association for Educational Communications and Technology. (2004). The Definition of Educational Technology. Pre-publication draft of a chapter for The Definition of Educational Technology. Bloomington, IN: AECT.

[2] Alkan, C., Şimşek, N. and Deryakulu, D. (2011). Eğitim Teknolojisine Giriş. Ankara: Önder Printing, 2011.

[3] Caffarella, E. P. (1999). The major themes and trends in doctorial dissertation research in educational technology from 1977 through 1998. Educational Media and Technology Yearbook, 25, 14-25.

[4] Erdoğmuş, U., F. and Çağıltay, K. (2009). Türkiye'de eğitim teknolojileri alanında yapılan master ve doktora tezlerinde genel eğilimler. XI. Academic Informatics Conference, Harran University, Şanlıurfa, Turkey (11-13 February 2009).

[5] Göktaş, Y., Küçük, S., Aydemir, M., Telli, E., Arpacık, Ö., Yıldırım, G. and Reisoğlu, İ. (2012). Türkiye'de Eğitim Teknolojileri Araştırmalarındaki Eğilimler: 2000-2009 Dönemi Makalelerinin İçerik Analizi. Educational Sciences: Theory \& Practice - 12(1), Winter 177-199.

[6] Hughes, D., (2016). Educational Technology Trends: What Teachers Should Know. Received date 02.02.2019 from https://study.com/academy/lesson/educational-technology-trends-what-teachersshould-know.html.

[7] Spector, J., M. (2013). Trends and Research Issues in Educational Technology. The Malaysian Online Journal of Educational Technology Volume 1, Issue 3.

[8] Sağbaş, E. A., Ballı, S., and Yıldız, T. (2016). Giyilebilir Akıllı Cihazlar: Dünü, Bugünü ve Geleceği. İçinde: XVIII Academic Informatics Conference, Aydın, Turkey. 
International Journal of Computer- Aided Technologies (IJCAx) Vol.6, No.1/2, April 2019

[9] Spector, J., M. (2013). Trends and Research Issues in Educational Technology. The Malaysian Online Journal of Educational Technology Volume 1, Issue 3.

[10] Sert, G. (2010). Öğretim teknolojileri eğitiminde yayınlanmış Türkiye adresli makalelerin içerik analizi. Unpublished Master Thesis, Hacettepe University, Ankara, Turkey.

[11] Uzunboylu, H. ve Karagozlu, D. (2015). Flipped classroom: a review of recent literatüre. World Journal on Educational Technology, Vol 7, No 2.

[12] Tuncay, N., Keser, H. and Uzunboylu, H. (2010). If knowledge is power why keep it secret? Procedia Social and Behavioral Sciences 2 (2010) 5650-5658. 